\title{
BioLink
}

Jurnal Biologi Lingkungan, Industri, Kesehatan

Available online http://ojs.uma.ac.id/index.php/biolink

\section{THE EFFECTIVENESS TEST OF ALOE VERA EXTRACT INHIBITING THE GROWTH OF STAPHYLOCOCCUS AUREUS BACTERIA}

\author{
Nurhidayanti* \\ DIV Medical Laboratory Technology Study Program, Institut Ilmu Kesehatan dan Teknologi \\ Muhammadiyah Palembang, Indonesia
}

Submited : 15-10-2021; Reviewed :23-11-2021; Accepted : 10-01-2022

*Corresponding author: E-mail : nuri89 vanti@yahoo.com

\begin{abstract}
Staphylococcus aureus bacteria are resistant to several kinds of antibiotics, so there is a need for natural antibiotics derived from plants, namely aloe vera. The objective of this study was to determine the effect of aloe vera leaf extract in inhibiting the growth of Staphylococcus aureus bacteria. The type of research used was experimental using the disc diffusion method with a total of 25 samples with five concentrations of $20 \%, 40 \%, 60 \%, 80 \%$ and $100 \%$ then the data were analyzed using the One Way ANOVA test. The result is that aloe vera extract can inhibit the growth of Staphylococcus aureus bacteria, it is proven by the presence of a disc zone at 100\% concentration with a diameter of $11.5 \mathrm{~mm}$. The results of statistical analysis with the One Way ANOVA test, in a value of 0.000, meaning that there was a significant difference. The conclusion obtained is that aloe vera extract can slow down the growth of Staphylococcus aureus bacteria but based on the standard value of sensitivity of an aloe vera extract bacteria with the highest concentration it cannot be used as an antibiotic because it is less than the standard value of $14 \mathrm{~mm}$.
\end{abstract}

Keywords: Aloe vera; Effectiveness; Staphylococcus aureus

How to Cite: Nurhidayanti. (2022). The Effectiveness Test of Aloe vera Extract Inhibiting The Growth Of Staphylococcus aureus Bacteria, BioLink: Jurnal Biologi Lingkungan, Industri dan Kesehatan, Vol. 8 (2): Hal. 145-151 


\section{INTRODUCTION}

Staphylococcus aureus is a grampositive bacterium that has a round morphology and can live in colonies like grapes and can secrete pigment substances. Staphylococcus aureus bacteria are usually found in the air, dust, waste, and can live in food and produce enterotoxins but have no effect on the outside of food, and signs of poisoning will appear, such as diarrhea, vomiting, hypothermia, nausea, weakness, and helpless. In addition, other diseases that can arise are infections in the hair follicles, infected wounds, meningitis and pneumonia (Adriani \& Lasti, 2014; Sunarti \& Paninsari, 2019).

Staphylococcus aureus bacteria are resistant to several kinds of antibiotics due to the wrong choice of the right antibiotic, inappropriate dosage, and undisciplined use of the drug. Staphylococcus aureus resistance to antibiotics, namely clavulanic acid, ampicillin, penicillin G, amoxicillin, ciprofloxacin, sulbenicillin, also chloramphenicol (Diyantika et al., 2017).

It will make the infection difficult to treat with these antibiotics, another way that can be used to control resistance to bacteria is to use antibiotics properly so there is the development of alternative drugs from natural ingredients that can inhibit the growth of Staphylococcus bacteria which is expected to be safer, more efficient, and effective by creating natural antibiotics from the body-plants that have the potential as antibiotics. One of the plants that is cheap and easily available to be used as natural antibiotics is Aloe vera (Country, 2014).

Aloe vera is one of a variety of medicinal plants. Aloe vera leaf extract contains many active substances including Saponins, Anthraqumonealonin, Barbaloin, Isobarbaloin, Anthrax Zero, Aloeemodin, Anthracenesiamat, chrysophanic acid, and Eteraloin resistant to Aloe vera can be used as antibacterial, antiseptic, and antibiotic. Aloe vera extract has some very good antibacterial activity, including against Staphylococcus aureus bacteria which is one of the causes of infection (Natsir, 2013).

As an antibacterial substance, Aloe vera has active substances such as tannins, saponins and flavonoids. Saponins are alkaloid substances that can destroy DNA and RNA in bacteria. Tannins as antibacterial substances are able to inactivate adhesins so that the bacteria are no longer attached to the epithelial cells of the host. The content of flavonoids in aloe vera is able to make bacterial cell walls lyse. The above mechanism can inhibit the growth of bacteria(Suryati et al., 2018)

The objetive of this research was to determine the effect of aloe vera extract in forming the inhibition zone of Staphylococcus aureus bacteria. The 
significance of this research is to inform the public of the benefits of aloe vera as an inhibitor of the growth of Staphylococcus aureus bacteria which is one of the causes of infectious diseases.

\section{MATERIALS AND METHODS}

The type of research used was experimental which was carried out at the microbiology laboratory of the Palembang Health Laboratory Center (BBLK) on 23 24 April 2021 with a total of 25 samples with 5 concentrations, namely $20 \%, 40 \%$, $60 \%, 80 \%$ and $100 \%$.

This research began with sterilizing the tools to be used and then making the media Muller Hinton Agar (MHA) as well as extracting aloe vera leaf peel which then the extract was filtered and evaporated using hotplate to get a thick Aloe vera leaf extract then the extract was made with five predetermined concentrations using the Concentration formula $\mathrm{E}=\frac{e}{e+a} \times 100 \%$ (Yusitta, 2018).

Before carrying out the extract sensitivity test, you must do a bacterial strain test because to find out whether the bacteria used was Staphylococcus aureus with the ATCC 25923 strain, a catalase test, coagulase test and gram staining re carried out. If the results obtained are appropriate then proceed to make a bacterial suspension according to the standard Mc Farland's turbidity was $0.50-0.62$ and directly inoculated Staphylococcus aureus ATCC 25923 into an MHA medium dish and then leveled, after the bacteria were inoculated, input paper discs from Aloe vera leaf extract at concentrations of $20 \%$, $40 \%, 60 \%, 80 \%, 100 \%$, and 1 negative and positive control which will be tested for bacterial incubation with an incubator at $37 \mathrm{oC}$ for 24 hours after completion of incubation. Bacterial growth was observed to see whether there was an inhibition zone that occurred (Made, 2015).

Data analysis was carried out by using a computer statistical test using the SPSS 16 program and using statistical analysis that was adjusted to the distribution of existing data. Existing data was then tested using one way ANOVA. If the data obtained had a significant difference, then it was continued using the Posthoc test using the Tukey HSD test to see how big the difference between concentrations was.

\section{RESULTS AND DISCUSSION}

Testing of Staphylococcus aureus strains was carried out to ascertain the type of bacteria. The test results data are presented in table 1.

Table 1. Bacterial Strain Test Results

\begin{tabular}{lc}
\hline \multicolumn{1}{c}{ Test Test } & Results \\
\hline Catalase & Bubble + \\
Coagulase & Agglutination + \\
Gram stain & Gram + Coccus + \\
\hline
\end{tabular}


Based on table 1 above, the catalase means it is Staphylococcus aureus because test showed that the bacteria produced it is pathogenic.

positive bubbles which meant that it was

The results of gram staining showed Staphylococcus aureus bacteria. that gram positive bacteria were in the Meanwhile, the results of the coagulase test form of cocci that emit a purple color in show that agglutination occurs, which gram staining, which can be seen in Figure

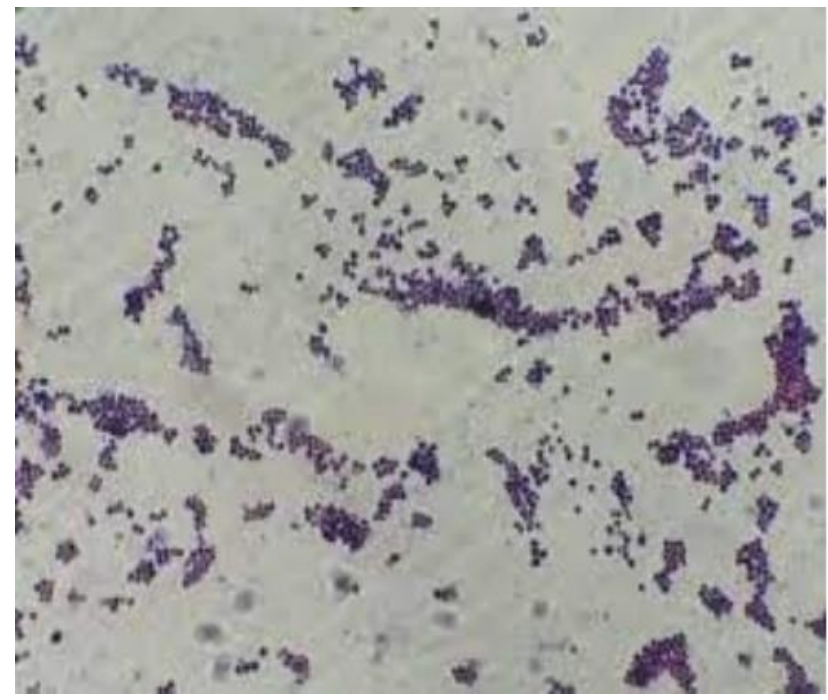

Figure 1. The Map of Research Location

Figure 1 above shows the purple The results of the test of the color caused by the bacteria trying to stay effectiveness of aloe vera extract as an with the first color, namely Crystal violet. inhibitor of the growth of Staphylococcus This result shows that the bacteria was aureus bacteria using various Staphylococcus aureus. (Hayati et al., 2019). concentrations obtained the following results:

Table 2. Results of Inhibition Zone of Aloe vera Extract

\begin{tabular}{cccccccc}
\hline \multirow{2}{*}{ Test } & $\begin{array}{c}\text { Control + } \\
(\mathbf{m m})\end{array}$ & \multicolumn{7}{c}{ Inhibition Zone (mm) } \\
\cline { 3 - 8 } & Controls - & $\mathbf{2 0 \%}$ & $\mathbf{4 0 \%}$ & $\mathbf{6 0 \%}$ & $\mathbf{8 0 \%}$ & $\mathbf{1 0 0 \%}$ \\
\hline P1 & 33 & 0 & 0 & 4 & 5 & 8 & 9 \\
P2 & 33 & 0 & 0 & 3 & 6 & 7 & 10 \\
P3 & 33 & 0 & 0 & 5 & 5 & 7 & 9 \\
P4 & 33 & 0 & 2 & 4 & 6 & 6 & 8 \\
P5 & 33 & 0 & 0 & 3 & 4 & 8 & 11.5 \\
\hline Average & $\mathbf{3 3}$ & $\mathbf{0}$ & $\mathbf{0 . 4}$ & $\mathbf{3 . 8}$ & $\mathbf{5 . 2}$ & $\mathbf{7 . 2}$ & $\mathbf{9 . 2}$ \\
\hline
\end{tabular}


In the results of table 2 above, it is clear that the positive control (as a comparison control) using the antibiotic novobiocin formed an inhibition zone of 33 $\mathrm{mm}$ and in the negative control using aquadest, no inhibition zone was formed at all. In the five types of concentrations used in this study, it can be seen that the inhibition zones formed were very varied, namely the larger the inhibition zone was formed along with the high concentration used (Rahardjo et al., 2017).

The greatest inhibition zone value was $11.5 \mathrm{~mm}$ at $100 \%$ aloe vera concentration. The sensitivity of bacteria to antibiotics was influenced by the diameter of the inhibition zoneat that was formed. The zone of inhibition in question is that there is no visible bacterial growth around the disc (Nurhidayanti, 2021).

Bacteria are declared sensitive if the inhibition zone on the disc and bacteria is $14 \mathrm{~mm}$ or more, it can be considered that the bacteria are sensitive to the suspension used, if the distance between the disc and the colony is $11 \mathrm{~mm}$, it can be said that the suspension is less effective in inhibiting bacterial growth (Mardiah, 2017). The inhibitory power of Aloe vera extract belongs to the medium category. The categorization of the inhibition zone was divided into 4 groups, namely: weak activity (less than $5 \mathrm{~mm}$ ), moderate activity ( 5 to $10 \mathrm{~mm}$ ), strong activity (less than 10 to $20 \mathrm{~mm}$ ), very strong activity (less than 20 to $30 \mathrm{~mm}$ ). The zone of inhibition around the disc is said to be the resistance to antimicrobials (Datta et al., 2019).

The results of statistical test data analysis using One Way ANOVA on aloe vera extract obtained a significant value of 0.000 meaning $\mathrm{p}=<0.05$ because the probability value is $\mathrm{p}=>0.05$ meaning there is a significant difference. The difference in question is the difference between the concentration used and the inhibition zone formed from the influence of the concentration because the $\mathrm{p}$ value $=$ $<0.05$. The results of this study are supported by previous research conducted by Tree et al., (2012) which obtained sig. $<0.05$, which means that there is a difference between the concentration of aloe vera leaf peel extract against Staphylococcus aureus and Escherichia coli bacteria (Tree et al., 2014).

The posthoc test data used the Tukey HSD test to determine the difference between concentrations based on the data obtained showing a significant difference with a $p$ value $<0.05$. There was a significant difference between the average bacterial growth at each treatment concentration. It proves that aloe vera leaf skin has effectiveness in inhibiting the growth of bacteria Staphylococcus aureus with active substances in Aloe vera such as phenols, saponins, tannins, 
anthraquinones. These compounds play an important role in the ability as an antibacterial. The phenolic compounds in aloe vera have a mechanism of inhibiting bacterial growth (Kadek et al., 2013).

Proteins in bacteria are able to bind to the above compounds through non-specific bonds to form a complex phenol protein, if the concentration is low, the complex phenol protein will decompose and the cytoplasmic membrane is damaged and causes leakage of the cell contents, as a result the growth of these bacteria can be inhibited. If the concentration is high, the substance will coagulate with cellular proteins resulting in lysis of the cytoplasmic membrane (Kadek et al., 2013). Saponins have antibacterial activity through decreasing cell surface tension, causing cell leakage and compounds in cells will come out (Gunawan, 2018).

The mechanism of action of tannins is to attack the cell wall in the polypeptide section to cause the cell wall to be imperfectly formed, it makes the cell wall in bacteria destroyed due to osmotic pressure and physical pressure makes bacterial cells die (Armiati, 2018).

Anthraquinone compounds are antimicrobial compounds with a broad spectrum. Aloe vera contains several anthraquinone glycosides (barbaloin, aloeemodin and aloin). The antibacterial properties of Aloe-emodin work by slowing the transfer of electrons in the mitochondrial respiratory system, where phenolics are compounds derived from phenol and can change the nature of bacterial proteins, by increasing the permeability of cells which causes cells to become blocked and damaged (Armiati, 2018).

\section{CONCLUSION}

The conclusion from the results of the research above is that the inhibition zone in each concentration has various diameters and the concentration that has the highest inhibition zone value is a concentration of $100 \%$ but based on the standard sensitivity of a bacterium, namely $14 \mathrm{~mm}$ of aloe vera leaf extract, it cannot be said to be effective as an antibiotics because the inhibition zone formed by $11.5 \mathrm{~mm}$ has not reached the sensitivity standard. The results of statistical tests there are significant differences in the inhibition zone formed from the effect of the given concentration. The higher the concentration of aloe vera extract, the larger the inhibition zone will be.

\section{REFERENCES}

Adriani, \& Lasti, M. Y. (2014). IDENTIFIKASI KEBERADAAN Staphylococcus sp PADA SANTAN KELAPA KEMASAN YANG DI PERDAGANGKAN DI KOTA MAKASSAR. Jurnal Biotek, 2(1), 31-34. http://journal.uinalauddin.ac.id/index.php/biotek/article/vie $\mathrm{w} / 1687$

Armiati, I. G. K. (2018). Penurunan Jumlah Koloni Streptococcus Mutans Dalam Rongga Mulut Oleh Ekstrak Etanol Kulit Daun Lidah Buaya. Interdental Jurnal Kedokteran Gigi 
(IJKG), 14(1), 1-4 https://doi.org/10.46862/ interdental.v14i1.364

Datta, F. U., Daki, A. N., Benu, I., Detha, A. I. R., Foeh, N. D. F. K., \& Ndaong, N. A. (2019). Uji aktivitas antimikroba bakteri asam laktat cairan rumen terhadap pertumbuhan Salmonella enteritidis, Bacillus cereus, Escherichia coli dan Staphylococcus aureus menggunakan metode difusi sumur agar. Prosiding Seminar Nasional VII Fakultas Kedokteran Hewan Universitas Nusa Cendana Swiss Bel-Inn Kristal Kupang, 6685 .

Diyantika, D., Mufida, D. C., \& Misnawi. (2017). Perubahan Morfologi Staphylococcus aureus Akibat Paparan Ekstrak Etanol Biji Kakao (Theobroma cacao) secara In Vitro The. Journal of Agromedicine and Medical Sciences, 3(1), 25-33.

Gunawan, D. H. (2018). PENURUNAN SENYAWA SAPONIN PADA GEL LIDAH BUAYA DENGAN PEREBUSAN DAN PENGUKUSAN Decreasing Saponin Compounds on Aloe Vera Gelwith Boiling and Steaming. Jurnal Teknologi Pangan, 9(1), 41-44.

Hayati, L. N., Tyasningsih, W., Praja, R. N., Chusniati, S., Yunita, M. N., \& Wibawati, P. A. (2019). Isolasi dan Identifikasi Staphylococcus aureus pada Susu Kambing Peranakan Etawah Penderita Mastitis Subklinis di Kelurahan Kalipuro, Banyuwangi. Jurnal Medik Veteriner, 2(2), 76.

https://doi.org/10.20473/jmv.vol2.iss2.2019. 76-82

Mardiah, M. (2017). Uji ResistensiStaphylococcus aureusTerhadap Antibiotik, Amoxillin, Tetracyclin dan Propolis. Jurnal Ilmu Alam Dan Lingkungan, 8(2), 1-6. https://doi.org/10.20956/jal.v8i16.2978

Natsir, N. A. (2013). Pengaruh ekstrak daun lidah buaya (Aloe vera) sebagai penghambat pertumbuhan bakteri Staphylococcus aureus. Prosiding FMIPA Universitas Pattimura 2013, 20-34.

Negara, K. (2014). Analisis Implementasi Kebijakan Penggunaan Antibiotika Rasional Untuk Mencegah Resistensi Antibiotika di RSUP Sanglah Denpasar: Studi Kasus Infeksi Methicillin Resistant Staphylococcus Aureus. Jurnal Administrasi Rumah Sakit Indonesia, $\quad 1(1), \quad 244383$. https://doi.org/10.1234/ arsi.vii1.2169

Ni Kadek Ariyanti, Ida Bagus Gede, S. K. S. (2013). DAYA HAMBAT EKSTRAK KULIT DAUN
LIDAH BUAYA (Aloe barbadensis Miller) TERHADAP PERTUMBUHAN BAKTERI Staphylococcus aureus ATCC 25923DAN Escherichia coli ATCC 25922. Jurnal Biologi, 16(1), 1-1. https://doi.org/10.24843/jbiounud

Nurhidayanti, T. A. I. (2021). Uji Efektivitas Ekstrak Rimpang Kunyit dan Perasan Jeruk Nipis Terhadap Pertumbuhan Staphylococcus aureus. 10, 68-74.

Rahardjo, M., Koendhori, E. B., \& Setiawati, Y. (2017). UJI AKTIVITAS ANTIBAKTERI EKSTRAK ETANOL LIDAH BUAYA (Aloe vera) TERHADAP BAKTERI Staphylococcus aureus. Jurnal Kedokteran Syiah Kuala, 17(2), 65-70.

https://doi.org/10.24815/jks.v17i2.8975

Sunarti, S., \& Paninsari, D. (2019). DAYA HAMBAT DAUN MANUKAN (Rhinacanthus nasutus (L) Kurz) TERHADAP BAKTERI STAPHYLOCOCCUS AUREUS SECARA IN VITRO. BIOLINK : Jurnal Biologi Lingkungan Industri Kesehatan, 6(2), 106113. doi:https://doi.org/10.31289/biolink.v6i2.273

Suryati, N., Bahar, E., \& Ilmiawati, I. (2018). Uji Efektivitas Antibakteri Ekstrak Aloe vera Terhadap Pertumbuhan Escherichia coli Secara In Vitro. Jurnal Kesehatan Andalas, 6(3), 518. https://doi.org/10.25077/ jka.v6.i3.p518-522.2017

Tree, W., Extract, B., Fahrimal, Y., Rafina, A., Azhar, A., \& Asmilia, N. (2014). PROFIL DARAH TIKUS PUTIH (Rattus norvegicus) YANG DIINFEKSIKAN Trypanosoma evansi DAN DIBERIKAN EKSTRAK KULIT BATANG JALOH (Salix tetrasperma Roxb). Jurnal Kedokteran Hewan - Indonesian Journal of Veterinary Sciences, 8(2). https://doi.org/10.21157/j.ked.hewan.v8i2.26 53

Yusitta, Y. (2018). EFEKTIVITAS EKSTRAK DAUN LIDAH BUAYA (Aloe vera L) terhadap PERTUMBUHAN Staphylococcus aureus DENGAN METODE DIFUSI. Advanced Optical Materials, 10(1), 1-9. https://doi.org/10.1103/PhysRevB.101.089902 \%oAhttp://dx.doi.org/10.1016/j.nantod.2015. o4.009\%oAhttp://dx.doi.org/10.1038/s41467 -018-055149\%oAhttp://dx.doi.org/10.1038/s41467-019138561\%oAhttp://dx.doi.org/10.1038/s41467-02014365-2\%oAhttp://dx.doi.org 